\title{
Training Needs of Agri Input Dealers
}

\author{
T. Jeyaprakash Narayanan ${ }^{1 *}$, J. Pushpa ${ }^{1}$, R. Velusamy ${ }^{1}$, \\ K. Prabhakaran ${ }^{2}$ and J. S. Amarnath ${ }^{3}$
}

${ }^{1}$ Department of Agricultural Extension and Rural Sociology, ${ }^{2}$ Department of Agricultural Economics, ${ }^{3}$ Department of Agricultural Economics, Agricultural College and Research Institute, Tamil Nadu Agricultural University, Madurai, Tamil Nadu, India

*Corresponding author

\section{A B S T R A C T}

Keywords

Farmers,

Agri input dealers,

plant protection

measures

\section{Article Info}

Accepted:

20 December 2020

Available Online:

10 January 2021
The present study was conducted during 2019-20 in Madurai district. A total 200 Agri input dealers were selected by proportionate allocation method from all the 12 blocks of Madurai District. Data were collected by using pretested well structured interview schedule. After thorough review of literature and in consultation with the experts of relevant field five different potential training areas viz., fertilizer, pesticides, seeds, farm machineries and ICT applications were identified and was measured by computing the weighted mean score Different areas of training were ranked as per the weighted mean score. The results revealed that more than two -third of the agro input dealers expressed their training needs on micro nutrients, liquid fertilizer, trade name, chemical name and properties of pesticides, weedicides, IPM and viability of seed aspects. Agri input dealers desire to have training on computer application in their agri business Hence institutions support to these input dealers must give undue important on their preference of training need areas while designing and conducting training programme.

\section{Introduction}

Farmers are mostly guided by the agri input dealers in selection and use of plant protection measures to control crops losses. Chronic toxicity of pesticides affect the whole population. The farming communities were found to be largely unaware of correct usage of pesticides. The outreach of agricultural universities and agricultural departments to the farmers was minimal due to less number of extension functionaries (Bhushan et al., 2013). Agri input dealers become one of the prime source of farm information and play a vital role in guaranteeing the essential agricultural inputs that contribute to boosting the agricultural productivity Ayieko and Tschirley (2006).

Modernization of agriculture involves mainlyinvention of agricultural technology, transfer of this technology and adoption of this technology. For transferring these technologies public extension services playing an important role. But, the public extension service by itself is not enough to 
handle the multifarious demands of the farming community and is being supplemented by private extension, agencies like NGOs, farmer organization etc.

Agri. entrepreneur playing important role in transfer of agricultural technology at level of extension linkage. So it is necessary to train the farm input dealers in respect of new technology so that they will change and adjust with new circumstances.

Training help to improve a person's skill power of intelligence and development in him the desired attitudes and values required for the work. To make the training programme more effective, training needs of the agri. entrepreneur have to be assessed before organizing of any training programme. Therefore, the present study was focused on the specific objectives to assess training needs of agri. entrepreneur (Agro input dealers).

\section{Materials and Methods}

The present study was conducted during 2019-20 in Madurai district. A total 200 input dealers were selected by proportionate allocation method from all 12 blocks of Madurai District. Data were collected by using pretested well structured interview schedule. After thorough review of literature and in consultation with the experts of relevant field the potential training areas were identified.

These areas were appraised by the respondents on three points continuing as most needed, needed, not needed for which scores of 3, 2 and 1 was assessed. Training need was measured by computing the weighted mean score and different areas of training were ranked as per the weighted mean score. Appropriate statistical tools were used to interpret data.

\section{Results and Discussion}

The training areas regarding input categories were divided into viz., pesticides, fertilizers, seeds, farm machineries and other viz. ICT application. These training areas were rated and presented in Table 1.,2,3,4 and 5 respectively

Training needs of agro input dealers in different areas of pest management Table 1 revealed that trade name chemical name and properties of pesticides have emerged as the most needed training area and is ranked first with weighted means score 2.84 followed by trade name, chemical name and properties of weedicides with weighted mean score of 2.7. Other identified perceived training areas were diagnostic and characteristic symptom and damage, caused by insect pest, integrated pest management(2.49), Maintenance, selection, use and care of different sprayers, dusters and their minor repairs with the mean weightage score value of 2.43. The findings of the study are in conformity with the study of farm input dealer Arjun Prasad Verma et al., (2019).

\section{Training needs related to fertilizers}

It could be observed from Table 2 that majority of the respondents had expressed most needed training needs on micronutrient fertilizer with the weighed score of 2.83 followed by liquid fertilizer and its method of application (2.81), different type of fertilizers (2.68) method of fertilizer application (2.62) integrated nutrient management (2.67) while respondents needed training need was expressed about soil testing of fertilizer(2.12) followed by cake fertilizer(2.02) and fertigation with the weighted score of (1.7). Findings of the study are in accordance with the study Waghmode et al., who revealed that respondents had expressed most needed training needs on micronutrient fertilizer. 
Table.1 Distribution on the basis of training needs of agri entrepreneur (agro-input dealers) in pest management $\mathrm{N}=200$

\begin{tabular}{|c|c|c|c|c|c|c|}
\hline $\begin{array}{l}\text { S. } \\
\text { No. }\end{array}$ & Training areas & $\begin{array}{c}\text { Most } \\
\text { needed* }\end{array}$ & Needed* & $\begin{array}{c}\text { Not } \\
\text { needed* }\end{array}$ & WMS* & Rank \\
\hline 1. & $\begin{array}{l}\text { Diagnostic and characteristics symptom and damage } \\
\text { caused by insect pest }\end{array}$ & $\begin{array}{l}166 \\
(83)\end{array}$ & $\begin{array}{c}9 \\
(4.5)\end{array}$ & $\begin{array}{c}25 \\
(12.5)\end{array}$ & 2.70 & II \\
\hline 2. & Identification of different type of pest & $106(53)$ & $26(13)$ & $68(34)$ & 2.19 & VIII \\
\hline 3. & $\begin{array}{l}\text { Trade name, chemical name and properties of } \\
\text { weedicides }\end{array}$ & 166 & $\begin{array}{c}9 \\
(4.5)\end{array}$ & $\begin{array}{c}25 \\
(12.5)\end{array}$ & 2.70 & II \\
\hline 4. & Control of non-insect pest rat, birds, termites, etc. & $124(62)$ & $60(30)$ & $16(8)$ & 2.54 & IV \\
\hline 5. & $\begin{array}{l}\text { Trade name, chemical name and properties of } \\
\text { pesticides }\end{array}$ & $170(85)$ & $\begin{array}{c}29 \\
(14.5)\end{array}$ & $1(0.5)$ & 2.84 & I \\
\hline 6. & IPM and its components & $\begin{array}{l}136 \\
(68)\end{array}$ & $\begin{array}{c}26 \\
(13)\end{array}$ & $38(19)$ & 2.49 & $\mathrm{~V}$ \\
\hline 7. & $\begin{array}{l}\text { Trade name, chemical name and properties of micro } \\
\text { nutrients }\end{array}$ & $\begin{array}{c}82 \\
(41)\end{array}$ & $\begin{array}{c}54 \\
(27)\end{array}$ & $64(32)-$ & 2.09 & IX \\
\hline 8. & $\begin{array}{l}\text { Maintenance, selection, use and care of different } \\
\text { sprayers, dusters and their minor repairs }\end{array}$ & $\begin{array}{c}86 \\
(43)\end{array}$ & 108 & $\begin{array}{c}6 \\
(3)\end{array}$ & 2.43 & VI \\
\hline 9. & $\begin{array}{l}\text { Precautions in handling-storing and use of antidotes in } \\
\text { case of accidents }\end{array}$ & $44(22)$ & $137(68.5)$ & $19(9.5)$ & 2.12 & VII \\
\hline 10. & Control of stored grain pests & $148(74)$ & $40(20)$ & $12(6)$ & $2 . .67$ & III \\
\hline 11. & Bio-fertilizer - its use and importance & $44(22)$ & $137(68.5)$ & $19(8.5)$ & 2.12 & VII \\
\hline
\end{tabular}

Note: *Figure in paranthesis indicates percentage

*WMS-Weighted mean score

Table.2 Distribution of respondents on the basis of training needs related to fertilizers

\begin{tabular}{|c|c|c|c|c|c|c|}
\hline $\begin{array}{l}\text { S. } \\
\text { No. }\end{array}$ & Training areas & $\begin{array}{l}\text { Most } \\
\text { needed* }\end{array}$ & Needed* & $\begin{array}{c}\text { Not } \\
\text { needed* }\end{array}$ & WMS* & Rank \\
\hline 1. & Different type of fertilizer & $\begin{array}{c}137 \\
(68.50)\end{array}$ & $\begin{array}{c}63 \\
(31.5)\end{array}$ & - & 2.68 & III \\
\hline 2. & Soil testing for fertilizer application & $60(30)$ & $\begin{array}{l}104 \\
(52) \\
\end{array}$ & $\begin{array}{c}36 \\
(18)\end{array}$ & 2.12 & $\mathrm{X}$ \\
\hline 3. & Methods of fertilizer application & $\begin{array}{l}130 \\
(65) \\
\end{array}$ & $\begin{array}{c}64 \\
(32) \\
\end{array}$ & $\begin{array}{c}6 \\
(3)\end{array}$ & 2.62 & VI \\
\hline 4. & $\begin{array}{l}\text { Government Laws and Regulations related } \\
\text { to fertilizer }\end{array}$ & $\begin{array}{l}110 \\
(55)\end{array}$ & $\begin{array}{c}78 \\
(39)\end{array}$ & $\begin{array}{l}12 \\
(6)\end{array}$ & 2.49 & VII \\
\hline 5. & Liquid fertilizer and method of used & $\begin{array}{c}161 \\
(80.5)\end{array}$ & $\begin{array}{c}34 \\
(17)\end{array}$ & $\begin{array}{c}5 \\
(2.5)\end{array}$ & 2.81 & II \\
\hline 6. & Bio-fertilizers & $\begin{array}{c}88 \\
(44)\end{array}$ & $\begin{array}{c}94 \\
(47)\end{array}$ & $\begin{array}{l}18 \\
(9)\end{array}$ & 2.35 & IX \\
\hline 7. & Micro-nutrients fertilizers & $\begin{array}{c}169 \\
(84.5)\end{array}$ & $\begin{array}{c}28 \\
(14.3)\end{array}$ & $\begin{array}{c}3 \\
(1.76)\end{array}$ & 2.83 & I \\
\hline 8. & Nutrient contents in fertilizers & $\begin{array}{c}147 \\
(73.5)\end{array}$ & $\begin{array}{c}39 \\
(19.5)\end{array}$ & $\begin{array}{l}14 \\
(7)\end{array}$ & 2.66 & $\mathrm{~V}$ \\
\hline 9. & Cake fertilizers & $\begin{array}{c}45 \\
(22.5)\end{array}$ & $\begin{array}{c}115 \\
(57.9)\end{array}$ & $\begin{array}{c}40 \\
(19.30)\end{array}$ & 2.02 & XI \\
\hline 10. & Fertigation & $\begin{array}{c}31 \\
(15.5)\end{array}$ & $\begin{array}{c}78 \\
(38.6)\end{array}$ & $\begin{array}{c}91 \\
(45.62)\end{array}$ & 1.7 & XII \\
\hline 11. & Implements used for fertilizer application & $\begin{array}{l}122 \\
(61)\end{array}$ & $\begin{array}{c}52 \\
(26.32)\end{array}$ & $\begin{array}{c}26 \\
(12.28)\end{array}$ & 2.48 & VIII \\
\hline 12. & Integrated Nutrient Management & $\begin{array}{c}145 \\
(72.5)\end{array}$ & $\begin{array}{c}45 \\
(22.5)\end{array}$ & $\begin{array}{l}10 \\
(5)\end{array}$ & 2.67 & IV \\
\hline
\end{tabular}

*Figure in paranthesis indicates percentage

*WMS-Weighted mean score 
Table.3 Distribution of respondents on the basis of training needs related to seeds

\begin{tabular}{|c|c|c|c|c|c|c|}
\hline $\begin{array}{l}\text { S. } \\
\text { No. }\end{array}$ & Areas of training & $\begin{array}{c}\text { Most } \\
\text { needed } *\end{array}$ & Needed* & $\begin{array}{c}\text { Not } \\
\text { needed } *\end{array}$ & WMS* & Rank \\
\hline 1. & $\begin{array}{l}\text { Improved varieties hybrids of } \\
\text { various crops }\end{array}$ & $\begin{array}{l}144 \\
(72)\end{array}$ & $\begin{array}{c}44 \\
(22)\end{array}$ & $\begin{array}{c}12 \\
(6)\end{array}$ & 2.66 & IV \\
\hline 2. & $\begin{array}{l}\text { Germination power of seed / } \\
\text { viability of seeds aspects }\end{array}$ & $\begin{array}{l}178 \\
(89)\end{array}$ & $\begin{array}{c}20 \\
(10)\end{array}$ & $\begin{array}{c}2 \\
(1)\end{array}$ & 2.67 & III \\
\hline 3. & Seed treatment & $\begin{array}{l}156 \\
(78)\end{array}$ & $\begin{array}{c}42 \\
(21)\end{array}$ & $\begin{array}{c}2 \\
(1)\end{array}$ & 2.77 & II \\
\hline 4. & Details of Certification of seeds & $\begin{array}{l}170 \\
(85)\end{array}$ & $\begin{array}{c}30 \\
(15)\end{array}$ & - & 2.85 & I \\
\hline 5. & Different type of seeds & $\begin{array}{l}124 \\
(62)\end{array}$ & $\begin{array}{c}69 \\
(34.5)\end{array}$ & $7(3.5)$ & 2.58 & V \\
\hline 6. & $\begin{array}{l}\text { Storage procedure and methods of } \\
\text { seeds }\end{array}$ & $\begin{array}{c}143 \\
(71.5)\end{array}$ & $\begin{array}{c}46 \\
(23)\end{array}$ & $11(5.5)$ & 2.66 & IV \\
\hline
\end{tabular}

Note: * Figure in paranthesis indicates percentage

*WMS-Weighted mean score

Table.4 Distribution of respondents on the basis of training needs on farm machines

\begin{tabular}{|c|l|c|c|c|c|c|}
\hline $\begin{array}{c}\text { S. } \\
\text { No. }\end{array}$ & \multicolumn{1}{|c|}{ Training areas } & $\begin{array}{c}\text { Most } \\
\text { needed* }\end{array}$ & Needed* & $\begin{array}{c}\text { Not } \\
\text { needed* }\end{array}$ & WMS* & Rank \\
\hline 1. & Repairing of machinery and & $\begin{array}{c}140 \\
\text { implements }\end{array}$ & $\begin{array}{c}32 \\
(70)\end{array}$ & $\begin{array}{c}(16) \\
28(14)\end{array}$ & 2.56 & II \\
\hline 2. & Operating skill & 110 & 60 & 30 & 2.4 & III \\
\hline 3. & $\begin{array}{l}\text { Insurance subsidy and loan } \\
\text { procedure }\end{array}$ & $\begin{array}{c}(55) \\
(85)\end{array}$ & $\begin{array}{c}(30) \\
(12)\end{array}$ & $\begin{array}{c}(15) \\
(5.5)\end{array}$ & 2.84 & I \\
\hline
\end{tabular}

*Figure in paranthesis indicates percentage

*WMS-Weighted mean score

Table.5 Distribution of respondents on the basis of crop specific training needs

\begin{tabular}{|c|c|c|c|c|c|c|}
\hline $\begin{array}{l}\text { S. } \\
\text { No. }\end{array}$ & Name of the crops & $\begin{array}{c}\text { Most } \\
\text { needed* }\end{array}$ & Needed* & $\begin{array}{c}\text { Not } \\
\text { needed }\end{array}$ & WMS* & Rank \\
\hline 1. & Cereals & $\begin{array}{l}150 \\
(75)\end{array}$ & $\begin{array}{c}40 \\
(20)\end{array}$ & $\begin{array}{l}10 \\
(5)\end{array}$ & 2.7 & II \\
\hline 2. & Pulses & $\begin{array}{l}120 \\
(60)\end{array}$ & $\begin{array}{c}60 \\
(30)\end{array}$ & $\begin{array}{c}20 \\
(10)\end{array}$ & 2.5 & III \\
\hline 3. & Millets & $\begin{array}{l}170 \\
(85)\end{array}$ & $\begin{array}{c}20 \\
(10)\end{array}$ & $\begin{array}{l}10 \\
(5)\end{array}$ & 2.8 & I \\
\hline 4. & Oilseeds & $\begin{array}{l}140 \\
(70)\end{array}$ & $\begin{array}{c}30 \\
(15)\end{array}$ & $\begin{array}{c}30 \\
(15)\end{array}$ & 2.55 & IV \\
\hline 5. & Horticultural Crops & $\begin{array}{l}170 \\
(85)\end{array}$ & $\begin{array}{c}20 \\
(10)\end{array}$ & $\begin{array}{l}10 \\
(5)\end{array}$ & 2.8 & I \\
\hline 6. & Commercial crops & $50(25)$ & $\begin{array}{c}30 \\
(15)\end{array}$ & $\begin{array}{l}120 \\
(60)\end{array}$ & 1.65 & V \\
\hline
\end{tabular}

*Figure in paranthesis indicates percentage

*WMS-Weighted mean score 
Table.5 Distribution of respondents on the basis of training needs in ICT application

\begin{tabular}{|c|l|c|c|c|c|c|}
\hline $\begin{array}{c}\text { S. } \\
\text { No. }\end{array}$ & \multicolumn{1}{|c|}{ Training areas } & $\begin{array}{c}\text { Most } \\
\text { needed }\end{array}$ & Needed* & $\begin{array}{c}\text { Not } \\
\text { needed* }\end{array}$ & WMS* & Rank \\
\hline 1. & $\begin{array}{l}\text { Computer knowledge and } \\
\text { operation }\end{array}$ & $180(90)$ & $14(7)$ & $6(2)$ & 2.87 & I \\
\hline 2. & E-mail, scanning & $112(56)$ & $60(30)$ & $28(14)$ & 2.42 & IV \\
\hline 3. & Internet (marketing) & $142(71)$ & $30(15)$ & $28(14)$ & 2.57 & III \\
\hline 4. & General record keeping software & $136(68)$ & $56(28)$ & $8(4)$ & 2.64 & II \\
\hline
\end{tabular}

*Figure in parenthesis indicates percentage

*WMS-Weighted mean score

\section{Training needs related to seeds}

From the table 3, it could be inferred that cent per cent of the agro input dealers needed training on details of certification of seeds with the weighed score 2.85 followed by seed treatment (2.77) germination power of seeds (2.67), information about the improved varieties / hybrids of various crop and storage procedure and methods of seed with the weighted score of 2.66 respectively.

Findings of the study are in accordance with the study of Arjun Prasad Verma (2019), Mande and Darade (2011)

With respect to training needs on farm machines, it could be observed that input dealers preferred training on insurance, subsidy and loan procedure to purchase farm equipment with mean weightage score of 2.84 followed by operating skill and repairing of machinery and implements with mean weightage score value of 2.56 and 2.4 respectively. This might be due to the fact that majority of the farmers required information related to the insurance subsidies and scheme availability etc for purchase of farm machine

It could be observed from table 5 that input dealers preferred training on horticultural crops and millets ranked as first with weightage score of 2.8 followed by cereals, pulses and oil seeds with the weightage score of 2.7, 2.5 and 2.55 respectively. Least preferred training on commercial crops with mean weightage score. This might be due to the fact that farmers and dealers were well aware of technologies of commercial crops because farmers themselves take care about the commercial crop than other crops.

It could be observed from table 5 that training on computer knowledge given top most priority by agro input dealers and which ranked first with the weightage score of 2.87 followed by general recorded keeping (2.64 WMS) Internet marketing with mean weightage score of 2.57. Application of modern ICT tool is essential for any business in providing update information. Majority of them required training on application of record keeping software to maintain all the activities of business.

In conclusion more than two -third of the agro input dealers expressed their training needs on micro nutrients, liquid fertilizer, trade name, chemical name and properties of pesticides, weedicides, IPM and viability of seed aspects. Agri input dealers desire to have training on computer application in their agri business. Hence institutions support to these input dealers must give undue important on their preference of training need areas while designing and conducting training programme. 


\section{Acknowledgement}

Authors would like to express sincere gratitude to the Tamil Nadu Government and Tamil Nadu Agricultural University to persue my Ph.D degree through part time mode and my sincere thanks also input dealers /servicers who willingly spare their valuable time and efforts in answering the question during data collection.

\section{References}

Ayieko MW, Tschivky DL 2006. Enhancing access and utilization of quality seed for improved food securities in Kenya working paper No 2/2006 Nairobi Kenya Tegemo Institute of Agricultural Policy and Development.

Arjun Prasad verma, Vimal Raj Yadav, Diksha Patel and Nishi Ray 2019. Relevance and utility of different training needs of input dealers in Jnansi district of Bundelkhand regun.
Asian Journal of Agricultural Extension, Economics and Sociology Bhushan C, Bhardwaj A, Misra SS.( 2013) State of Pesticide Regulations in India, Centre for Science and Environment, New Delhi;

Mande JV, Darade NW2011. Training Needs of Farm Input Dealers for Transfer of Agricultural Technology. Journal of Community Mobilization and Sustainable Development.;6(2):14114.

Singh AK, De HK, Pal PP(20150. Training Needs of Agro-input Dealers in South 24Parganas District of West Bengal. IndianRes. J. Ext. Edu. 15(2):7-10.

.Waghmode YJ, Desai AN, Sawant PA. (2014)Training needs of agricultural input dealers in transfer of agriculture technology in Ratnagiri district of Konkan region. Agriculture Update. 9(4):543-546.

\section{How to cite this article:}

Jeyaprakash Narayanan, T., J. Pushpa, R. Velusamy, K. Prabhakaran and Amarnath, J. S. 2021. Training Needs of Agri Input Dealers. Int.J.Curr.Microbiol.App.Sci. 10(01): 3036-3041. doi: https://doi.org/10.20546/ijcmas.2021.1001.353 